\title{
Mental Poisons to Upset Yourself
}

\author{
Montse Rovira* \\ Licensed Clinical Psychologist, Spain
}

*Corresponding author: Montse Rovira, Licensed Clinical Psychologist, Spain

\begin{abstract}
"The only thing that is happening to you is that you are awfulizing," Ellis said to his clients. Albert Ellis (Pittsburgh, 1913 - Manhattan, 2007) was the creator of Rational Emotive Behavior Therapy (REBT) with which he revolutionized the field of Psychology by being the first one to develop a model of psychotherapeutic intervention with a cognitive approach. Ellis used his ironic sense of humor teaching his clients to laugh at themselves in order to relativize their own problems and begin to confront them from a less dramatic and irrational perspective.
\end{abstract}

\section{Short Communication}

Mental poisons are addictive psychologically toxic thought habits. Many times people consider the need to ask for psychological help with the belief that they have a mental disorder, they are going crazy, or something must not work correctly in their brain to feel so downcast, hopeless, and unable to avoid emotional discomfort. Also it is common to feel as victims of a kind of conspiracy that prevents them from being happy, and it seems that different aspects of life align to upset them. They do not find satisfaction in relationships, in work, nor in family life. Nor do they feel good about themselves. The future, much more than uncertain, seems stormy, foreign and contrary to their aspirations. They feel irremissibly miserable. "People don't just get upset. They contribute to their upsetness and do it constantly!", Ellis said. Ellis identified the most widespread and "effective" habits of thought in order to become authentic miserable people. He even invented a terminology of his own to name them. These mentally unhealthy habits are irrational beliefs that become a kind of mental poison that with use and abuse poison our way of thinking and gives rise to what he called "the most habitual ways to become neurotic". The tendency to poison our thinking comes from those irrational beliefs which, as we have always believed them, we consider valid. We think it is the world that does not work and we do not recognize our own contribution in suffering discomfort, therefore we attribute the cause of our suffering to something external. We continue once and again drinking the poison that we create in our mind, while we hope that something will change externally and will allow us to reach the goal to experience serenity and happiness. The principle mental poisons that Ellis identified are the following:

Awfulizing: This happens when our beliefs make us think that anything is terrible, horrifying, or catastrophic. We believe that this is the worst thing that could happen to me. We awfulize when the unfulfillment of our desires is accompanied by a formulation of them so rigid that they are no longer wishes, but strong rigid demands. When the awfulizing has taken over our way of thinking, it spreads like a virus to the most trivial aspects of life and we end up considering any trifle as something terrible if it does not correspond to our expectations. We identify the fulfillment of our desire as the source of happiness, and its unfulfillment as a great tragedy that will prevent us from being happy over and over.

I Can't Stand It: In this case we see an event or experience as something unbearable. It comes from a misconception of what is bearable and what is not. We are used to immediate satisfaction and we have no frustration tolerance. If we are hungry, we can buy something precooked and heat it in the microwave to quickly satisfy our appetite and not have to endure hunger while we cook. If we have a slight pain, we go to an analgesic to relieve it in a few minutes. If we want to communicate with someone we send a text message and then we keep watching the phone waiting for that someone to answer to us immediately. But we can't always get an immediate response to our expectations. If we generalize these 
behaviors to any aspect of life, we are encouraging a low frustration tolerance. I can't stand it means that the presumed cause of the discomfort should disappear as soon as possible, be it the behavior of a person that we can't stand, a situation that we can't stand, or conditions that we cannot bear. Awfulizing and cannot standing usually go hand in hand when we tell ourselves: It is terrible that this happens, and if it did, I could not stand it: hence, poison added to another poison.

Musturbating (or Shoulding): This is another term coined by Ellis. In this case our demands about how life should be, how others should treat us, or how we ourselves should be or act, are rigid and inflexible demands. It seems unheard to us if life is not as it should be, that people do not always treat us as they must do it, or that we are not able to be or do what we should. There is a divergence between our demands and reality, and we turn that divergence into the source of discomfort. We are overburdened with obligations (shoulds), and are convinced that this is normal, socially common, and essential for happiness. Then we tell ourselves: I should have a stable, satisfactory and well-paid job, I should form a happy family, I should have many friends, I should be intellectually brilliant, I should live comfortably, I should travel whenever I feel like, I should speak languages, I should keep fit, I should be attractive, I should have an interesting social life ... etc. The amount of should we go on accumulating is ridiculous. Let's simply ask ourselves what our grandparents would think if we explained to them everything, we have to achieve to be happy. Ellis said that the only thing really necessary for life is oxygen, drink and food. Everything else is preferable, desirable, pleasant, and convenient, but not absolutely necessary.

Negative Global Self-Evaluation: Through the dysfunctional tendency to exaggerate and globalize our failures, we do not say I was wrong, but I am a failure. We transform an isolated event into a label with which we personally identify and therefore each time consider ourselves useless, unworthy, stupid, etc. It is one of the most dangerous poisons with which we can feed our mental dialogue since it affects our emotions making us really feel in the way that we have labeled ourselves. And of course, if we consider ourselves stupid and feel stupid, we in turn behave stupidly; things will go bad for us and they will become an evidence that we are really stupid. Not only do we label our person, but we also do it with others, and even with life. To think rationally we have to keep in mind the idea that we can make mistakes, but that does not mean we are failures. Do not confuse the wrong actions that we can commit with our worth as human beings.

These are, according to Dr. Ellis, the best ways to upset ourselves, to screw up, to feel miserable and to inflame our cognitive processes in turn poisoning our mind, feelings, and behavior. The worst part is not that we feel miserable, but that we insist on it by our mental dialogue. It is common that when one of these bad habits is installed in our way of thinking, we adopt one, two, or maybe all of them. We do it completely unconsciously since they are so ingrained in us that we are not able to detect them objectively. Ellis created REBT as an antidote to these poisons and, thanks to it, millions of people have transformed their lives. The radical difference between a healthy and unhealthy mind is the perception of what events mean to us. We feel according to our interpretation of events. Ellis stated that we think irrationally when we disturb ourselves and, to feel healthy emotions, we have to challenge the unhelpful perceptions. If we look carefully at our thoughts and discover any of these kind of poisons, we better stop thinking that way and change our mindset. Any time is a good time to eliminate mental poisons and adopt new habits that will help us to be psychologically healthy people.

\section{References}

1. Ellis A (1958) Rational psychotherapy. Journal of General Psychology 59(1): 35-49.

2. Ellis A (1973) Humanistic psychotherapy: The RET approach. McGraw Hill, New York, USA

3. Ellis A (1984) Expanding the ABC of RET. In A Freeman, M Mahoney (Dirs.), Cognition and psychotherapy. Plenum, New York, USA 2(2): 20 24.

4. Ellis A (1994) Reason and emotion in psychotherapy: Revised and updated. Birch Lane, New York, USA.

5. Ellis A (2009) All Out! An Autobiography. Prometheus books, New York, USA.

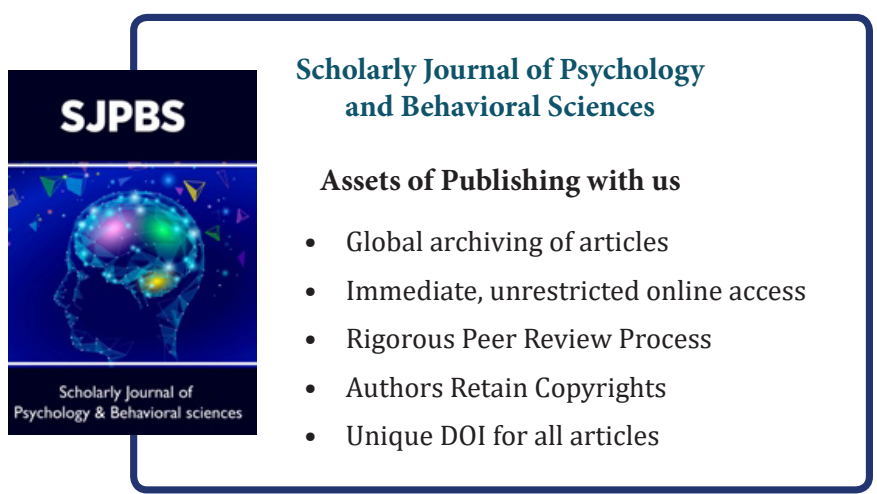

